\title{
ENSAT Staging Finding v7
}

National Cancer Institute

\section{Source}

National Cancer Institute. ENSAT Staging Finding v7. NCI Thesaurus. Code C104016.

A finding about one or more characteristics of adrenal cancer, following the rules of the ENSAT staging v7 classification system. 